\title{
A Novel Purification Procedure for Active Recombinant Human DPP4 and the Inability of DPP4 to Bind SARS-CoV-2
}

\author{
Cecy R Xi ${ }^{1}$, Arianna Di Fazio ${ }^{1}$, Naveed Ahmed Nadvi ${ }^{1,2}{ }^{,}$Karishma Patel ${ }^{3}{ }^{\circledR 0}$,

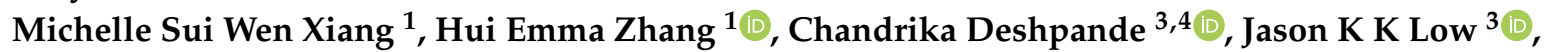 \\ Xiaonan Trixie Wang ${ }^{1}$, Yiqian Chen ${ }^{1}$, Christopher L D McMillan ${ }^{5}{ }^{\circ}$, Ariel Isaacs ${ }^{5}$, \\ Brenna Osborne ${ }^{1} \mathbb{D}$, Ana Júlia Vieira de Ribeiro ${ }^{1}$, Geoffrey W McCaughan ${ }^{1,6}$, Joel P Mackay ${ }^{4}(\mathbb{D}$, \\ W Bret Church ${ }^{7}(\mathbb{D})$ and Mark D Gorrell ${ }^{1, * \mathbb{C}}$ \\ 1 Centenary Institute, Faculty of Medicine and Health, The University of Sydney, \\ Sydney, NSW 2006, Australia; c.xi@centenary.org.au (C.R.X.); arianna.difazio@path.ox.ac.uk (A.D.F.); \\ naveed.nadvi@sydney.edu.au (N.A.N.); m.xiang@centenary.org.au (M.S.W.X.); \\ e.zhang@centenary.org.au (H.E.Z.); t.wang@centenary.org.au (X.T.W.); yiqian.chen@hudson.org.au (Y.C.); \\ brenna@sund.ku.dk (B.O.); anajulia.vribeiro@gmail.com (A.J.V.d.R.); \\ g.mccaughan@centenary.org.au (G.W.M.) \\ 2 Research Portfolio Core Research Facilities, The University of Sydney, Sydney, NSW 2006, Australia \\ 3 Faculty of Science, School of Life and Environmental Sciences, The University of Sydney, \\ Sydney, NSW 2006, Australia; kpat7951@uni.sydney.edu.au (K.P.); \\ chandrika.deshpande@sydney.edu.au (C.D.); jason.low@sydney.edu.au (J.K.K.L.) \\ 4 Drug Discovery, Sydney Analytical, Core Research Facilities, The University of Sydney, \\ Sydney, NSW 2006, Australia; joel.mackay@sydney.edu.au \\ 5 School of Chemistry and Molecular Biosciences, The University of Queensland, \\ St Lucia, QLD 4072, Australia; c.mcmillan1@uq.edu.au (C.L.D.M.); ariel.isaacs@uq.net.au (A.I.) \\ 6 AW Morrow GE \& Liver Centre, Royal Prince Alfred Hospital, Camperdown, NSW 2050, Australia \\ 7 Faculty of Medicine and Health, School of Pharmacy, The University of Sydney, \\ Sydney, NSW 2006, Australia; bret.church@sydney.edu.au \\ * Correspondence: m.gorrell@centenary.org.au; Tel.: +61-2-9565-6156; Fax: +61-2-9565-6101
}

Received: 15 September 2020; Accepted: 13 November 2020; Published: 18 November 2020

\begin{abstract}
Proteases catalyse irreversible posttranslational modifications that often alter a biological function of the substrate. The protease dipeptidyl peptidase 4 (DPP4) is a pharmacological target in type 2 diabetes therapy primarily because it inactivates glucagon-like protein-1. DPP4 also has roles in steatosis, insulin resistance, cancers and inflammatory and fibrotic diseases. In addition, DPP4 binds to the spike protein of the MERS virus, causing it to be the human cell surface receptor for that virus. DPP4 has been identified as a potential binding target of SARS-CoV-2 spike protein, so this question requires experimental investigation. Understanding protein structure and function requires reliable protocols for production and purification. We developed such strategies for baculovirus generated soluble recombinant human DPP4 (residues 29-766) produced in insect cells. Purification used differential ammonium sulphate precipitation, hydrophobic interaction chromatography, dye affinity chromatography in series with immobilised metal affinity chromatography, and ion-exchange chromatography. The binding affinities of DPP4 to the SARS-CoV-2 full-length spike protein and its receptor-binding domain (RBD) were measured using surface plasmon resonance and ELISA. This optimised DPP4 purification procedure yielded 1 to $1.8 \mathrm{mg}$ of pure fully active soluble DPP4 protein per litre of insect cell culture with specific activity $>30 \mathrm{U} / \mathrm{mg}$, indicative of high purity. No specific binding between DPP4 and CoV-2 spike protein was detected by surface plasmon resonance or ELISA. In summary, a procedure for high purity high yield soluble human DPP4 was achieved and used to show that, unlike MERS, SARS-CoV-2 does not bind human DPP4.
\end{abstract}


Keywords: recombinant protein; protease; DPP4; Covid-19

\section{Introduction}

Dipeptidyl peptidase 4 (DPP4), also known as CD26 and adenosine deaminase binding protein (ADAbp), is a $110 \mathrm{kDa}$ type II transmembrane glycoprotein belonging to the DPP4 gene family of serine proteases. DPP4 is widely expressed on endothelial, epithelial and immune cells in mammalian tissues and has multifunctional roles in metabolism, immunology, endocrinology, fibrosis and cancer [1-6]. DPP4 is often cleaved from cell surfaces to be released into extracellular spaces as an enzymatically active, soluble form that has intact protein-protein binding activities [7-10]. Soluble DPP4 has been associated with a variety of diseases as a potential biomarker and is largely derived from damaged hepatocytes and activated lymphocytes $[3,10,11]$. DPP4 expression can be stimulated by hypoxia [12].

The soluble form of DPP 4 is composed of an $\alpha / \beta$-hydrolase domain and an eight-blade $\beta$-propeller domain with an active site located at the interphase of the two domains $[9,13,14]$. DPP4 preferentially cleaves after proline or alanine in the penultimate position from the $N$-terminus of polypeptides. DPP4 cleavage of the incretin peptides, glucagon-like peptide-1 (GLP-1) and gastric inhibitory polypeptide (GIP), have led to the development of DPP4 selective inhibitors as a successful type 2 diabetes mellitus (T2DM) therapy [4,15-18]. The outer surface of the propeller domain of DPP4 contains binding sites for other proteins, most notably the non-catalytic binding with human adenosine deaminase (ADA) $[7,9,19,20]$. DPP4 association with ADA has a co-stimulatory role in human T-cell activation [10]. The immunoregulatory and cardiovascular roles of DPP4 may be important in viral infections [10,21-23].

The MERS-CoV and SARS-CoV-2 epidemics arose about eight years apart. These viruses have a 50\% genetic similarity [24]. MERS-CoV arose in 2012, and 2519 infections and 866 deaths have been reported [25], whereas SARS-CoV-2 caused more than 500,000 deaths within seven months. Infection by coronavirus is mediated by the binding of the surface spike glycoprotein to a host cell receptor via the receptor-binding domain (RBD) in the S1 subunit of the spike. MERS-CoV coronavirus infection is mediated by the S1 spike glycoprotein binding to DPP4 on a site that overlaps with the ADA binding site on the $\beta$-propeller domain of DPP4 [26,27]. Recent modelling of the homotrimer structure of SARS-CoV-2 spike has predicted a similar ability to bind to DPP4 [28]. Angiotensin-converting enzyme 2 (ACE2) has been experimentally validated as a high-affinity entry receptor for SARS-CoV-2 [29-33]. However, the potential binding interaction between DPP4 and SARS-CoV-2 is yet to be directly evaluated.

Molecular investigations on protein structure, function, substrates and binding partners require reliable methods to produce and purify DPP4. The most common approaches for expressing enzymatically active recombinant human DPP4 uses baculovirus-infected insect cells $[13,14,34,35]$, and less commonly mammalian and yeast cells [10,36]. Baculovirus-insect expression systems have many advantages over mammalian and yeast expression systems, including the ease of use, adequate glycosylation, appropriate codon usage and potentially greater expression [37,38]. Although glycosylation of recombinant proteins in insect cells is less complex than the native human glycoproteins, it has produced stable and active soluble recombinant human DPP4 proteins [13].

Most commonly, recombinant soluble human DPP4 has been purified from insect cell cultures as an affinity-tagged protein using only immobilised metal affinity chromatography (IMAC) and size-exclusion chromatography $[13,34,35,39]$. Monomeric DPP4 is inactive, whereas dimeric and tetrameric forms are active, so we explored methods that avoided separation by size. We have shown that DPP4 activity is intolerant of $C$-terminal truncation, but tolerates some $N$-terminal truncations [40], so the affinity tag was attached to the $C$-terminus to maximise capture of active DPP4 by an IMAC resin. Here, we report an optimised 4-step purification strategy for His ${ }_{6}$-tagged soluble recombinant human 
DPP4 protein from Sf9 insect cells that achieved high purity. The purified DPP4 was used to measure the extent of binding with SARS-CoV-2 spike using ELISA and surface plasmon resonance (SPR).

\section{Results}

\subsection{The Expression and Purification of DPP4}

A His 6 -tagged soluble form of human DPP4 (residues 29 to 766) was generated in a pMelbac baculovirus vector as we have described previously [35]. When stored in sterile conditions below $10{ }^{\circ} \mathrm{C}$, with glycerol to prevent freezing, DPP4 activity in cell culture supernatants did not detectably diminish within seven years. This form of soluble DPP4 is stable and fully active in both enzyme activity and ADA binding [10,41]. For this study, the recombinant virus was further cloned to select for increased DPP4 production. Enzyme activity is dependent on the structural integrity of these proteins $[3,40,42]$. Hence, expression levels were assessed by measuring the enzymatic activity of cell cultures. DPP4 expression was optimised by varying the quantity of virus for infection and the time to harvest. The time course of enzymatic activity after infection showed that robust enzyme expression was achieved 7 days post-infection. Overall, a $1 \mathrm{~L}$ suspension of Sf9 cells $\left(1.2-2.2 \times 10^{6}\right.$ cells $\left./ \mathrm{mL}\right)$ was infected at a multiplicity of infection (MOI) of 1 and harvested 7 days post-infection for large-scale DPP4 protein expression.

DPP4 protein was purified in four-steps: Ammonium sulphate (AS) precipitation, hydrophobic interaction chromatography (HIC), dye affinity chromatography in series with IMAC, and ion-exchange chromatography (IEX) (Figure 1). The purification process was monitored by measuring specific activity, with the goal of achieving $>20 \mathrm{U} / \mathrm{mg}$ because above $20 \mathrm{U} / \mathrm{mg}$ has been established as the specific activity of highly purified DPP4 [8].

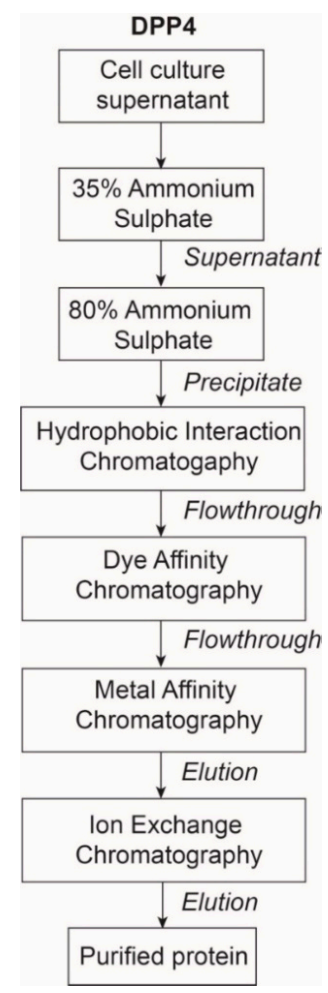

Figure 1. Overview of DPP4 purification workflow.

For a preliminary separation of DPP4 from contaminants in the cell culture supernatant, precipitation at $35 \%$ AS saturation followed by $80 \%$ AS saturation was performed (Figure S1) [35]. This step improved enzyme purity 7-fold with a 59\% yield (Table 1). Next, to exploit the presence of AS and remove some contaminating hydrophobic proteins, HIC using Phenyl Sepharose with $12 \%$ AS 
was performed, similar to a previous study [43]. HIC produced two major elution peaks: The first peak represents unbound non-hydrophobic soluble DPP4 in the flowthrough and the second peak represents contaminants eluted from the Phenyl Sepharose column with a $\%$ AS buffer (Figure 2A).

(A)

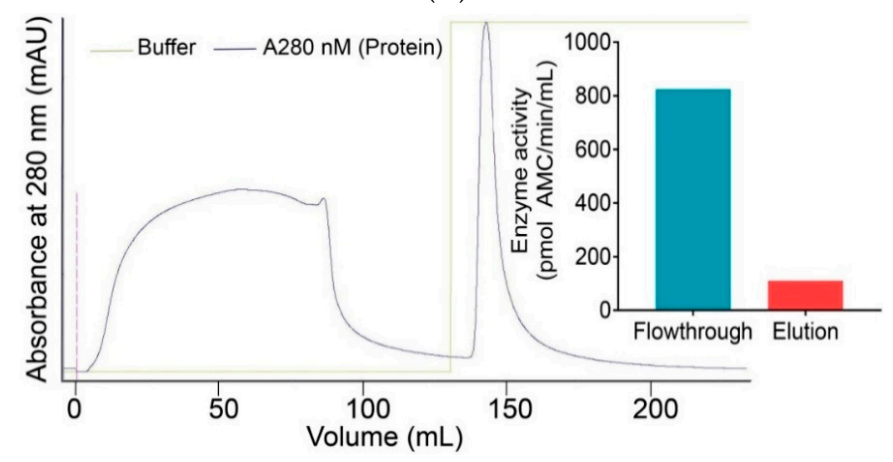

(B)

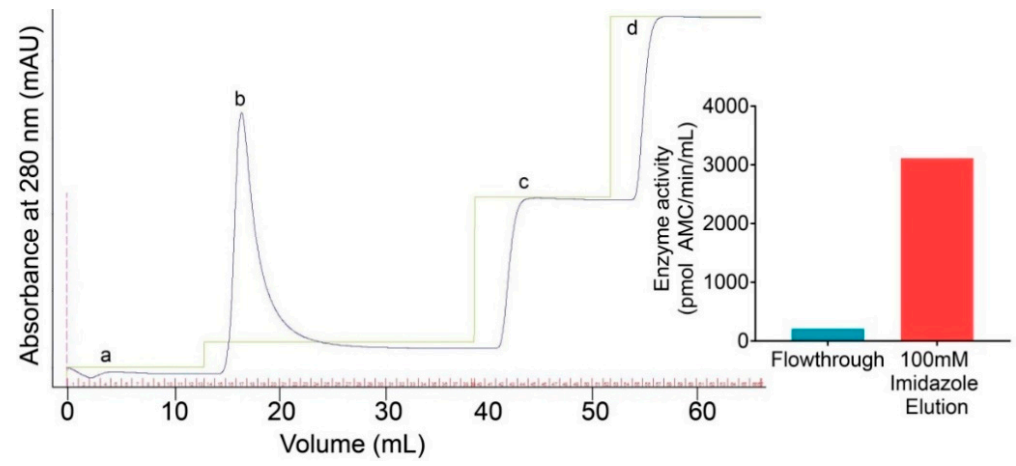

(C)

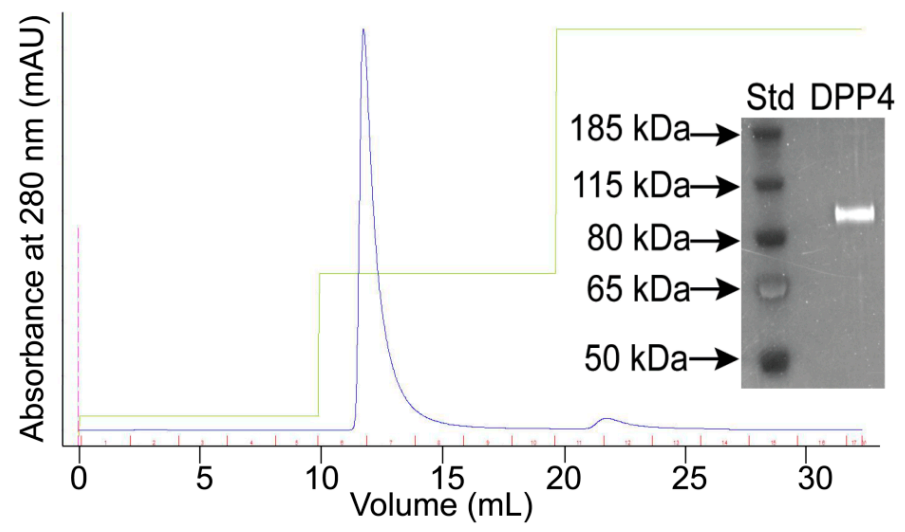

Figure 2. Elution profiles of DPP4 chromatography. (A) Chromatogram from Phenyl Sepharose that was equilibrated with $12 \%$ ammonium sulphate (AS) in $10 \mathrm{mM}$ Tris- $\mathrm{HCl} \mathrm{pH} 7.6$ and eluted with $0 \%$ AS in $10 \mathrm{mM}$ Tris- $\mathrm{HCl} \mathrm{pH} 7.6$ buffer. Inset: Fibroblast activation protein (FAP) activity. (B) Chromatogram from Nickel Sepharose, which was equilibrated with $20 \mathrm{mM}$ imidazole in $200 \mathrm{mM} \mathrm{NaCl}, 10 \mathrm{mM}$ Tris-HCl, $\mathrm{pH} 7.6$ and eluted with an increasing concentration gradient of imidazole at $30 \mathrm{mM}(\mathrm{a}), 100 \mathrm{mM}(\mathrm{b})$, $500 \mathrm{mM}$ (c), $1000 \mathrm{mM}$ (d) in $10 \mathrm{mM}$ Tris-HCl pH 7.6 buffer. Inset: FAP activity. (C) Chromatogram from DEAE Sepharose that was equilibrated with $10 \mathrm{mM}$ Tris- $\mathrm{HCl} \mathrm{pH} 7.6$ and eluted with $200 \mathrm{mM} \mathrm{NaCl}$ in $10 \mathrm{mM}$ Tris-HCl pH 7.6 buffer. Inset: sodium dodecyl sulphate polyacrylamide gel electrophoresis (SDS-PAGE; 4-12\% Bis-Tris gel) of the resulting purified soluble DPP4, stained with Sypro ruby Protein was measured by optical density at $280 \mathrm{~nm}$ in these chromatograms.

Blue Sepharose dye affinity chromatography binds to albumin and some other contaminants [44] and did not bind to DPP4. DPP4 protein was then captured from the solution by IMAC that was 
directly attached downstream in series with the Blue Sepharose column. The IMAC technique utilises the affinity of exposed poly-histidine towards charged transition metals, such as $\mathrm{Ni}^{2+}$, immobilised on a chelated chromatography resin. An increasing concentration gradient of imidazole at $30 \mathrm{mM}$, $100 \mathrm{mM}, 500 \mathrm{mM}$ and $1000 \mathrm{mM}$ revealed that DPP4 eluted from the Nickel Sepharose column at $100 \mathrm{mM}$ imidazole, in a single sharp peak (Figure 2B). Imidazole at $30 \mathrm{mM}$ eluted little or no DPP4. Therefore, subsequent purification runs loaded the IMAC in $30 \mathrm{mM}$ imidazole and eluted DPP4 with $100 \mathrm{mM}$ imidazole. IMAC was the central and most effective purification step, increasing the DPP4 protein purity to $>40 \mathrm{U} / \mathrm{mg}$ specific activity with a $46 \%$ yield and losing only $16 \%$ of the DPP4 that was loaded onto IMAC (Table 1). IMAC achieved greater than 2000-fold purification compared to culture supernatant.

To concentrate the DPP4, the DPP4-enriched fractions from IMAC were combined for IEX on DEAE Sepharose. As IEX was performed at pH 7.6, DPP4 was expected to be negatively charged ( $\mathrm{pI}$ is approximately 6) and bind to the positively charged DEAE Sepharose. Bound DPP4 proteins were eluted with $200 \mathrm{mM} \mathrm{NaCl}$, seen as a sharp peak on the chromatogram (Figure 2C). A second smaller peak was observed, which did not contain DPP4 activity and may represent protein contaminants that bind more tightly to the IEX resin. This final IEX step concentrated the DPP4, while maintaining purity (judged by specific activity); whereas, it decreased yield to $29 \%$ and caused a $35 \%$ loss of DPP4 (Table 1).

Table 1. Representative purification of DPP4 from Sf9 cells.

\begin{tabular}{|c|c|c|c|c|c|c|c|c|c|}
\hline & $\begin{array}{l}\text { Volume } \\
\text { (mL) }\end{array}$ & $\begin{array}{l}\text { Protein } \\
(\mathrm{mg} / \mathrm{mL})\end{array}$ & $\begin{array}{l}\text { Total } \\
\text { Protein } \\
\text { (mg) }\end{array}$ & $\begin{array}{l}\text { Total } \\
\text { Activity } \\
\text { (U) }\end{array}$ & $\begin{array}{c}\text { Specific } \\
\text { Activity } \\
\text { (U/mg) }\end{array}$ & $\begin{array}{c}\text { Fold- } \\
\text { Purification * }\end{array}$ & $\begin{array}{l}\text { Yield } \\
(\%)^{* *}\end{array}$ & $\begin{array}{l}\text { Step-Wise } \\
\text { DPP4 Loss } \\
\text { (\%) \# }\end{array}$ & $\begin{array}{c}\text { Step-Wise } \\
\text { Total Protein } \\
\text { Loss }(\%) \# \#\end{array}$ \\
\hline $\begin{array}{l}\text { Cell culture } \\
\text { supernatant }\end{array}$ & 1000 & 7.3 & 7300 & 144 & 0.020 & 1 & 100 & 0 & 0 \\
\hline $35 \%$ AS & 1046 & 3.9 & 4079 & 109 & 0.027 & 1.4 & 76 & 24 & 44 \\
\hline $80 \%$ AS & 82 & 7.2 & 589 & 85 & 0.14 & 7.0 & 59 & 22 & 86 \\
\hline $\begin{array}{c}\text { Phenyl } \\
\text { Sepharose }\end{array}$ & 93 & 4.1 & 381 & 77 & 0.20 & 10 & 53 & 9.4 & 35 \\
\hline Ni Sepharose & 41 & 0.034 & 1.4 & 64 & 46 & 2300 & 44 & 16 & 99.6 \\
\hline $\begin{array}{c}\text { DEAE } \\
\text { Sepharose }\end{array}$ & 4.4 & 0.23 & 1.0 & 42 & 42 & 2100 & 29 & 35 & 29 \\
\hline
\end{tabular}

* Fold-purification is specific activity after the step/specific activity of the starting material (cell culture supernatant). ** Yield is Units of DPP4 as a \% of DPP4 Units in the starting material. \# Step-wise DPP4 loss (\%) is $100 \times($ total activity after the previous step - total activity after this step)/total activity after the previous step. \#\# Step-wise total protein loss $(\%)$ is $100 \times$ (total protein after previous step - total protein after this step)/total protein after the previous step.

The purified DPP4 was analysed by SDS-PAGE with Sypro ruby and Colloidal blue stains. Heating samples for PAGE monomerises DPP4 and thereby simplifies the interpretation of gels. A single protein band was obtained near the expected molecular mass of monomeric DPP4 (Figure 2C, Figure S2). The calculated monomeric size of DPP4 (29-766) is $88.3 \mathrm{kDa}$ and glycosylation occurring in this expression system is limited [14]. When stored in sterile conditions, the purified DPP4 was very stable at $0{ }^{\circ} \mathrm{C}$ to $30{ }^{\circ} \mathrm{C}$, and when $10 \%$ glycerol was added activity was undiminished for more than a year in storage below $0{ }^{\circ} \mathrm{C}$. For example, two activity measurements made 15 months apart were 11.7 and $11.2 \mathrm{U} / \mathrm{mL}$.

The mean specific activity of the purified DPP4 enzyme obtained from five separate purification runs was $36 \mathrm{U} / \mathrm{mg}$ (Table 2). This optimised protocol yielded, on average $1.4 \mathrm{mg}$ of DPP4 protein per litre of suspension cell culture (Table 2). 
Table 2. DPP4 purification yields and specific activity from five replicate experiments.

\begin{tabular}{cccccc}
\hline $\begin{array}{c}\text { Purification } \\
\text { Replicate }\end{array}$ & $\begin{array}{c}\text { Culture } \\
\text { Supernatant (L) }\end{array}$ & $\begin{array}{c}\text { Total Protein } \\
\mathbf{( m g )}\end{array}$ & $\begin{array}{c}\text { Enzyme } \\
\text { Activity } \\
\mathbf{( U / m L )}\end{array}$ & $\begin{array}{c}\text { Specific } \\
\text { Activity } \\
\mathbf{( U / m g )}\end{array}$ & $\begin{array}{c}\text { Final Yield } \\
(\mathbf{m g} / \mathbf{L} \text { Culture) }\end{array}$ \\
\hline 1 & 1 & 1.2 & 45 & 37 & 1.2 \\
\hline 2 & 1.1 & 1.2 & 52 & 43 & 1.1 \\
\hline 3 & 0.98 & 1.5 & 44 & 29 & 1.6 \\
\hline 4 & 0.98 & 1.8 & 61 & 34 & 1.9 \\
\hline 5 & 0.99 & 1.0 & 42 & 40 & 1.0 \\
\hline Mean \pm SD & $1.0 \pm 0.1$ & $1.3 \pm 0.3$ & $49 \pm 7.8$ & $36 \pm 5.4$ & $1.4 \pm 0.4$ \\
\hline
\end{tabular}

\subsection{DPP4, MERS-CoV and SARS-CoV-2}

The expected ability of DPP4 to bind to MERS spike was shown by ELISA (Figure 3A), with a $\mathrm{K}_{\mathrm{d}}$ of $0.06 \mu \mathrm{g} / \mathrm{mL}$. In a pseudovirus inhibition assay, DPP4 at $20 \mu \mathrm{g} / \mathrm{mL}$ inhibited MERS-CoV pseudovirus entry, with 37\% inhibition detected (Figure 3B).
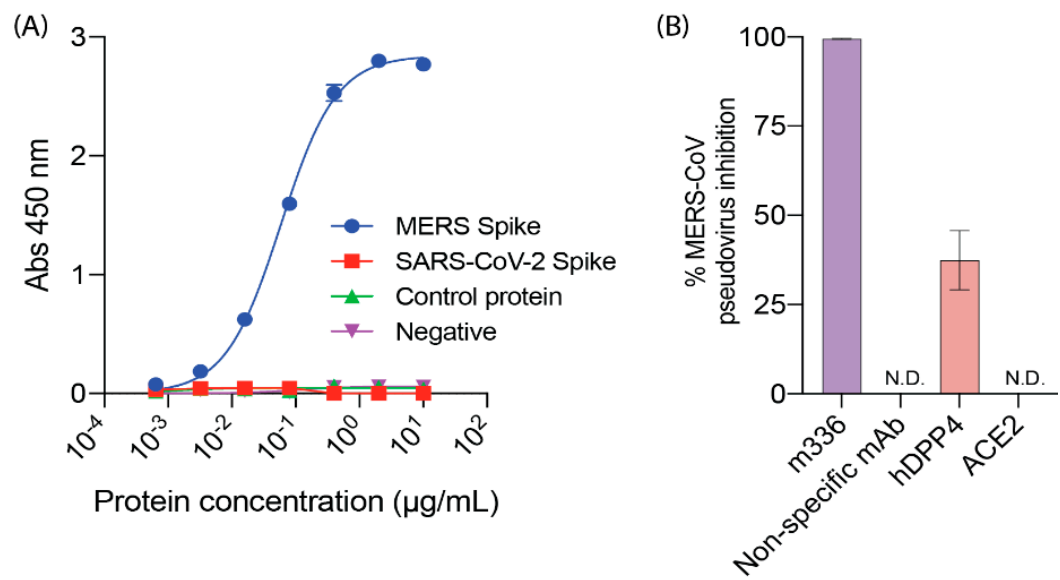

Figure 3. ELISA and virus neutralisation assays. (A) Purified DPP4 protein was used to capture MERS-CoV spike clamp, SARS-CoV-2 spike clamp or a control clamped protein. Clamp-stabilised proteins were detected using a clamp-specific mAb HIV1281. Data shown represent means of duplicate values. (B) DPP4, ACE2, a MERS-specific mAb m336 or a non-specific mAb C05 were used at $20 \mu \mathrm{g} / \mathrm{mL}$ and incubated with MERS-CoV pseudovirus. Percent MERS-CoV inhibition is the percentage reduction in luciferase signal (RLU) compared to virus-only control. N.D. indicates no inhibition detected. Data shown are the mean of duplicate values with error bars representing SD.

To investigate the binding affinity of DPP4 to SARS-CoV-2 RBD and full-length spike, SPR assays were performed. Experiments were initially performed by immobilising SARS-CoV-2 spike and RBD on a biotin CAPture chip. The positive control, ACE2, was able to bind with SARS-CoV-2 spike with a dissociation constant $\left(\mathrm{K}_{\mathrm{d}}\right)$ of $40 \mathrm{nM}$ and with SARS-CoV-2 RBD with a $\mathrm{K}_{\mathrm{d}}$ of $14 \mathrm{nM}$ (Figure S3). However, non-specific binding of DPP4 to the biotin CAPture chip was detected, resulting in slightly negative sensorgrams (Figure S3). Therefore, the specificity of the binding interaction between DPP4 and SARS-CoV-2 spike and SARS-CoV-2 RBD could not be determined by that method.

The SPR assay was then performed by immobilising SARS-CoV-2 spike and RBD on a CM5 chip. ACE2 readily bound to RBD with a $\mathrm{K}_{\mathrm{d}}$ of $100 \mathrm{nM}\left(\mathrm{k}_{\mathrm{on}} 1.7 \times 10^{5} \mathrm{M}^{-1} \mathrm{~s}^{-1} ; \mathrm{k}_{\text {off }} 1.7 \times 10^{-2} \mathrm{~s}^{-1}\right)$, and to spike with a $\mathrm{K}_{\mathrm{d}}$ of $0.34 \mathrm{nM}\left(\mathrm{k}_{\text {on }} 3.3 \times 10^{7} \mathrm{M}^{-1} \mathrm{~s}^{-1} ; \mathrm{k}_{\text {off }} 1.0 \times 10^{-2} \mathrm{~s}^{-1}\right)$ (Figure $\left.4 \mathrm{~A}\right)$. In contrast, no specific binding between DPP4 and either RBD or spike glycoprotein of SARS-CoV-2 was detectable in this assay (Figure 4B). Given the concentrations used, we can infer that any interaction between DPP4 and the spike protein would have a dissociation constant of $\sim 10 \mu \mathrm{M}$ or weaker. 

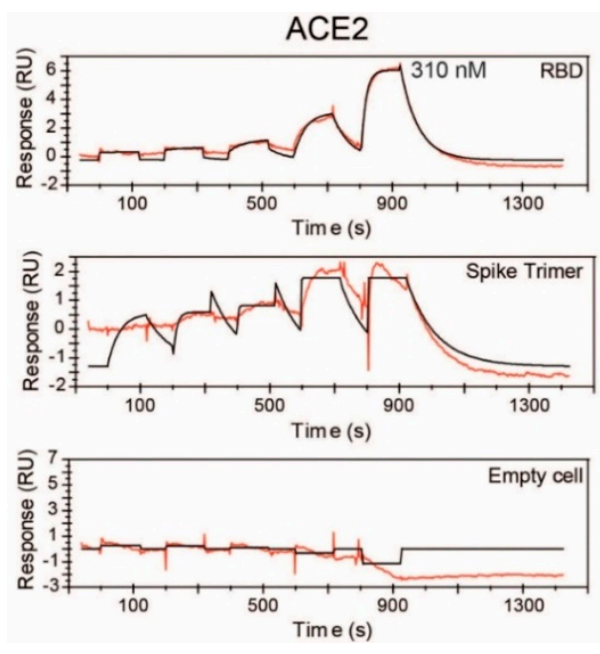

(A)
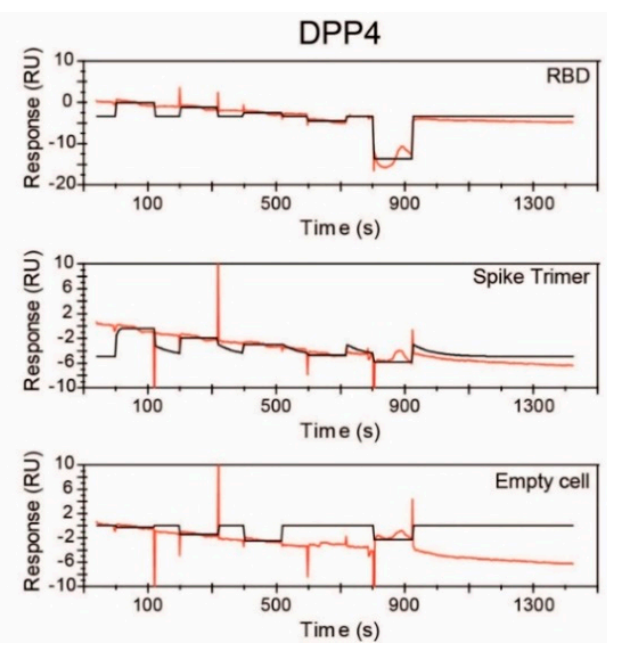

(B)

Figure 4. Surface plasmon resonance assays. Purified soluble human ACE2 (A) and DPP4 (B) were exposed to CM5 chips that had been coated with SARS-CoV-2 RBD or spike protein, or were not coated. Experimental data are shown in red. Calculated data fit using a 1:1 binding model are shown in black. Ligands were injected at increasing concentrations of (A) ACE2 at $0.50 \mathrm{nM}, 2.5 \mathrm{nM}, 12 \mathrm{nM}, 62 \mathrm{nM}$ and $310 \mathrm{nM}$ and (B) DPP4 at $1.6 \mathrm{nM}, 8.0 \mathrm{nM}, 40 \mathrm{nM}, 200 \mathrm{nM}$ and $1000 \mathrm{nM}$.

\subsection{Protein Structures: Depictions of Binding Surfaces}

The protein binding surfaces of the relevant proteins are depicted in Figure 5. The predicted binding sites on DPP4 of ADA, MERS RBD and CoV-2 RBD substantially overlap and are located on blades 4 and 5 of the b-propeller domain of DPP4 [28,45,46]. These three binding sites, of the known ligands and a proposed ligand of DPP4, are similar in their display of some concavity. In contrast, the binding surface on DPP4 is flatter and not complementary in shape. Thus, the topology of each ligand is similar despite very little sequence similarity between ADA and MERS spike. Additionally, there are similarities between how DPP4 binds to MERS RBD and to ADA-in that both interactions are amphiphilic and include a hydrophobic interaction involving Leu294 of DPP4, as well as hydrogen bonding and a salt bridge. The predicted binding site on CoV-2 is somewhat similar to MERS, with predicted van der Waals and hydrogen bonding, but differs in surface charge. Glycans might be important on spike [47]; however, sugars on DPP4 are not in the binding site (Figure 5) so might not be involved on DPP4.

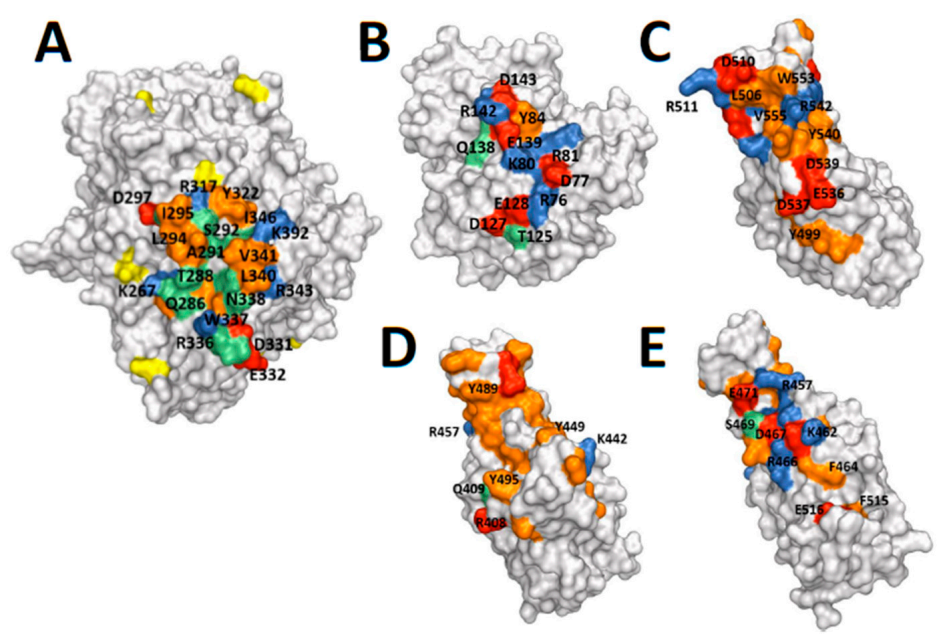

Figure 5. Protein structures. (A) DPP4 monomer (PDB ID 1W1I) [46]. (B) Adenosine Deaminase 
(ADA) (PDB ID 1W1I) [46]. (C) MERS-CoV spike RBD (PDB ID 4L72) [45], and (D,E) SARS-CoV-2 spike RBD (PDB ID 6M0J) [48] shown with space-filling surfaces with similar orientation and scale. The observed and predicted interfacial binding sites are highlighted in green, with the charged residues highlighted in red (negative) and blue (positive), and the hydrophobic residues are highlighted in orange. In particular, compared to the other molecules SARS-CoV-2 spike RBD has an extensive hydrophobic surface, and fewer charged residues at the predicted DPP4 binding site that is in a similar location to MERS-CoV spike RBD (D) [28], but has more charges surfaces on the opposite side of SARS-CoV-2 spike RBD, which is a potential alternative binding site (E) [28]. The N-glycosylated residues in DPP4 are highlighted in yellow, and are sufficiently distant from the binding interface to expect that they do not bind to ADA [20].

\section{Discussion}

In this study, we developed an optimised purification method for high yields of active pure soluble recombinant human DPP4 with specific activities above $30 \mathrm{U} / \mathrm{mg}$. We showed that purified human DPP4 can bind MERS-CoV spike, but unable to bind either SARS-CoV-2 RBD or SARS-CoV-2 full-length spike. Soluble recombinant active human DPP4 has been purified from insect cells previously using IMAC, with final recoveries of around $20 \%$ and comparable specific activities [13,34,35]. The optimised four-step purification strategy developed in this study allowed us to achieve pure soluble human DPP4 from insect cells with recoveries above $20 \%$ and yields of up to $1.8 \mathrm{mg}$ and 50 Units per litre of cell culture.

Our novel DPP4 purification procedure included AS precipitation and HIC to remove abundant contaminants that can increase the viscosity of the solution and column pressure in subsequent chromatography steps. A tandem dye affinity chromatography and IMAC approach was employed to further remove impurities with little loss of DPP4 prior to IMAC. This approach minimised the number of chromatographic steps and removed many contaminants prior to IMAC, while minimising time, cost and DPP4 loss, and avoiding size separation that risks removing active oligomeric DPP4. The acidic isoelectric point of DPP4 permits IEX, which was used as a concentration step that maintained final purity above 2000 -fold. This pure DPP4 has good stability at $4{ }^{\circ} \mathrm{C}$, as has been observed for natural purified DPP4 [49].

Receptor recognition is an essential early step for coronavirus entry into a cell. The purified soluble human DPP4 protein allowed us to examine its potential interaction with SARS-CoV-2 RBD and full-length spike glycoprotein by SPR. In this study, human ACE2, as an identified entry receptor for SARS-CoV-2, strongly bound to the RBD and full-length spike glycoprotein of SARS-CoV-2. In contrast, DPP4 did not bind in this sensitive assay. Mediation of SARS-CoV-2 entry in non-permissive cells, HeLa and BHK21 that lack human ACE2 has also been shown to be independent of human DPP4 [29,32,33]. These data suggest that human DPP4 is neither an entry receptor nor co-receptor used by SARS-CoV-2. We previously showed that DPP4 from this expression construct is intact and fully active [35,50], and so able to bind to its ligands. Moreover, the enzyme activity of the human DPP4 molecule requires both the $\alpha / \beta$-hydrolase domain and the eight-blade $\beta$-propeller domain to be intact [43]. Nevertheless, the ability of our DPP4 to bind MERS-CoV spike was verified. Therefore, the inability of our DPP4 to bind SARS-CoV-2 spike is very unlikely to be caused by a defect in the DPP4.

Comparing protein structures provides some understanding of why DPP4 does not bind to CoV-2 RBD. The observed difference in areas of surface charge on SARS-CoV-2 spike compared to the DPP4 binding site on MERS spike offered a potential reason for the observed difference in binding. A limitation of this analysis is that, in nature, proteins can change shape or bind to a different site on the cognate receptor.

In conclusion, we established and optimised a purification protocol for active recombinant soluble human DPP4 that can yield 1 to $1.8 \mathrm{mg}$ of pure protein per litre of insect cell suspension culture. The availability of large quantities of human soluble DPP4 proteins facilitates further structural studies and substrate and inhibitor discovery to enhance the biochemical understanding of this protease for developing therapeutics for MERS, diabetes, cancer, fibrosis and atherosclerosis. 


\section{Materials and Methods}

\subsection{Materials}

Spodoptera frugiperda 9 (Sf9) insect cells and Cellfectin II Reagent were from Invitrogen (Carlsbad, CA, USA). Escherichia coli DH5 $\alpha$ cells were from Thermo Fisher Scientific (Waltham, MA, USA). X-Gal was from Bio-Rad (Hercules, CA, USA). Insect-XPRESS medium was from Lonza (Basel, Switzerland). Enzyme substrate H-Gly-Pro-pNA was from Bachem (Bubendorf, Switzerland). Chromatography resins and materials for SPR were from Cytiva (Chicago, IL, USA). SnakeSkin Dialysis Tube, 3.5 kDa molecular weight cut-off (3.5 k MWCO), was purchased from Thermo Fisher Scientific. All other reagents were from Sigma-Aldrich (St. Louis, MO, USA).

\subsection{Expression and Purification of Active Soluble Human DPP4}

\subsubsection{Expression of DPP4 in Insect Sf9 Cells}

Soluble human DPP4 (residues 29-766; GenBank M80536) was cloned with a C-terminal His ${ }_{6}$-tag into the pMelbac vector and expressed according to the Bac-N-Blue baculovirus expression system protocol (Thermo Fisher Scientific) [35]. The expression plasmid construct was transformed into E. coli DH5 $\alpha$ cells. Positive clones were identified by restriction digest and Sanger Sequencing (The Australian Genome Research Facility; Westmead, NSW, Australia).

Insect Sf9 cells were maintained in Insect-XPRESS medium at $27^{\circ} \mathrm{C}$ as either adherent cultures, or as suspension cultures by shaking at $130 \mathrm{rpm}$. Adherent Sf9 cells $\left(1 \times 10^{6}\right.$ cells/well in a 6-well plate $)$ were transfected with recombinant bacmid DNA using Cellfectin II Reagent. The cells were monitored every $24 \mathrm{~h}$ by bright-field microscopy to observe cell lysis. Around $72 \mathrm{~h}$ post-transfection, the cell culture supernatant was harvested. Plaque assays were performed to identify positive recombinant stocks. To perform the plaque assay, Sf9 cells $\left(5 \times 10^{6}\right.$ cells/100-mm-plate) were prepared and incubated at $27^{\circ} \mathrm{C}$ for 12 to $24 \mathrm{~h}$. Serial dilutions from $10^{-1}$ to $10^{-4}$ of the transfection viral stock were prepared, and viral dilution at $1 \mathrm{~mL}$ was added per plate. The medium was incubated for $1 \mathrm{~h}$ at $27^{\circ} \mathrm{C}$ and aspirated from the plate. An agarose solution at $5 \mathrm{~mL}$, which included $50 \mu \mathrm{g} / \mathrm{mL}$ X-Gal (5-bromo-4-chloroindol-3-yl $\beta$-D-galactopyranoside), was laid over the cells [51]. Plates were then incubated at $27^{\circ} \mathrm{C}$ for 7 to 10 days.

Positive recombinant stocks (P0) identified from the plaque assay were used to infect fresh Sf9 cells in 96-well plates $\left(3.6 \times 10^{4}\right.$ cells/well) for screening and selecting the most productive recombinant virus clones [52]. Dilutions of virus to give $5 \mathrm{pfu} /$ well and $0.5 \mathrm{pfu} /$ well were used to infect the Sf9 cells. When cell viability reached $<30 \%$, DPP4 expression was measured by enzyme activity assay. Clones with the greatest DPP4 enzyme activity were selected and used to infect fresh Sf9 cells to generate P1 baculovirus stock.

To passage the baculoviral stocks, P1 baculovirus stock was used to infect a fresh $10 \mathrm{~mL}$ Sf9 $\left(2 \times 10^{6}\right.$ cells $\left./ \mathrm{mL}\right)$ suspension culture at an MOI of 0.05 to generate P2 baculovirus. Similarly, P2 baculovirus stock was used to infect $500 \mathrm{~mL}$ of Sf9 cells to generate high-titre P3 baculovirus working stock. For large scale protein expression, Sf9 suspension cultures were infected with the recombinant P3 baculovirus stock at an MOI of 1 in Insect-XPRESS medium for 7 days. The virus titres of P3 stocks were determined by plaque assay, as described above, using a dilution of $10^{-1}$ to $10^{-7}$. The virus titre $(\mathrm{pfu} / \mathrm{mL})$ was calculated as $(1 /$ dilution $) \times$ number of plaques.

\subsubsection{Purification of DPP4}

Cell culture supernatant was clarified $(5375 \times g$ for $10 \mathrm{~min}$ ) then solid ammonium sulphate (AS) was added to $35 \%(w / v)$ at $25^{\circ} \mathrm{C}$, and the precipitate was discarded following centrifugation at $25,800 \times g$ for $30 \mathrm{~min}$ at $4{ }^{\circ} \mathrm{C}$. To the supernatant, $80 \%$ AS was added, then, following $25,800 \times g$ for $30 \mathrm{~min}$ at $4{ }^{\circ} \mathrm{C}$, the precipitate was retained. The precipitate was solubilised in $10 \mathrm{mM}$ Tris- $\mathrm{HCl}, \mathrm{pH} 7.6$, then dialysed 
against $12 \%$ AS in 50 to 100 sample volumes of Buffer A (12\% AS in $10 \mathrm{mM}$ Tris- $\mathrm{HCl}$, pH 7.6) overnight at $4{ }^{\circ} \mathrm{C}$. Following centrifugation at $26,000 \times \mathrm{g}$ for $20 \mathrm{~min}$ at $4{ }^{\circ} \mathrm{C}$, the supernatant was retained.

Column chromatography used the ÄKTA purifier ${ }^{\mathrm{TM}}$ system (Cytiva). A Phenyl Sepharose column $(2 \times 5 \mathrm{~mL})$ was equilibrated with Buffer A and the flowthrough collected. The bound proteins were eluted with Buffer B (10 mM Tris-HCl, pH 7.6) and discarded. The Phenyl Sepharose flowthrough was dialysed overnight at $4{ }^{\circ} \mathrm{C}$ against Buffer $\mathrm{C}(200 \mathrm{mM} \mathrm{NaCl}$ in $10 \mathrm{mM}$ Tris- $\mathrm{HCl}$, pH 7.6). A Blue Sepharose column $(1 \times 5 \mathrm{~mL})$ was attached upstream of a Nickel Sepharose column and were both equilibrated with $20 \mathrm{mM}$ imidazole in Buffer C. Imidazole at $20 \mathrm{mM}$ was added to the dialysed sample, which was then applied to these columns. DPP4 was eluted from the Nickel Sepharose $(1 \times 5 \mathrm{~mL})$ column with $100 \mathrm{mM}$ imidazole in Buffer C. The eluted fractions were dialysed overnight against Buffer $B$ and then applied to a DEAE Sepharose column $(2 \times 1 \mathrm{~mL})$ that had been pre-equilibrated with Buffer B. DPP4 was eluted from the DEAE column with Buffer $C$. The purified proteins were stored in Buffer $\mathrm{C}$ with $1 \mathrm{mM}$ EDTA and $10 \%$ glycerol at $-80{ }^{\circ} \mathrm{C}$. Glycerol is necessary as a cryopreservative, and EDTA prevents inhibition of DPP4 by metal ions [53].

\subsection{Expression and Purification of SARS-CoV-2 Full-Length Spike, SARS-CoV-2 RBD, and Human ACE2}

\subsubsection{Generation of Expression Constructs}

The expression plasmid for soluble trimeric SARS-CoV-2 spike protein (residues 1-1208) was generously provided by Dr Florian Krammer (Icahn School of Medicine, Mt Sinai) [54,55]. The SARS-CoV-2 spike expression construct includes the proteins native signal peptide (residues 1-14) to enable secretion, proline substitutions at residues 986 and 987 for stability, a GSAS substitution at the furin cleavage site (residues 682-685), and an $\mathrm{N}$-terminal $\mathrm{His}_{6}$-tag to allow purification. The SARS-CoV-2 receptor-binding domain (RBD) of the spike protein (residues 328-531) was cloned into the pCAGGS expression plasmid with an $\mathrm{N}$-terminal IgK signal peptide, to target the protein for secretion, and a C-terminal His 9 -tag and Avitag ${ }^{\mathrm{TM}}$ to enable purification. The soluble domain of the human ACE2 receptor (residues 1-614) was cloned into the pcDNA3.1 expression plasmid with a $C$-terminal His 9 -tag and Avitag ${ }^{\text {TM }}$ to enable purification. The native signal peptide of ACE2 (residues 1-18) was included to allow secretion of the protein upon expression. To allow specific enzymatic biotinylation of proteins possessing an Avitag TM, full-length E. coli biotin ligase BirA was cloned into pcDNA3.1 with an $\mathrm{N}$-terminal Cd4 signal peptide, to enable secretion of the protein, and no tag for affinity purification.

4.3.2. Expression and Purification of SARS-CoV-2 Full-Length Spike, SARS-CoV-2 RBD, and Human ACE2

SARS-CoV-2 full-length spike, SARS-CoV-2 RBD, and human ACE2 were expressed in EXPI293FTM cells at $37^{\circ} \mathrm{C}$ using transient transfection with $25 \mathrm{kDa}$ linear polyethyleneimine (PEI). EXPI293F ${ }^{\mathrm{TM}}$ cells were transfected at a cell density of $3 \times 10^{6}$ cells $/ \mathrm{mL}$ with pre-formed DNA-PEI complexes $(2 \mu \mathrm{g} / \mathrm{mL}$ DNA and $8 \mu \mathrm{g} / \mathrm{mL}$ PEI), and cultures were harvested $72 \mathrm{~h}$ post-transfection by centrifugation at $4000 \times g$ for $20 \mathrm{~min}$. Supernatants from the centrifugation were supplemented with $20 \mathrm{mM} \mathrm{HEPES} \mathrm{pH} 8.0$ and were passed over Ni-NTA agarose equilibrated with a buffer comprising $20 \mathrm{mM} \mathrm{NaH}_{2} \mathrm{PO}_{4} \mathrm{pH} 8.0$, $500 \mathrm{mM} \mathrm{NaCl}$, and $20 \mathrm{mM}$ imidazole for purification via His-tag affinity chromatography. Proteins were eluted from the Ni-NTA agarose using a buffer containing $20 \mathrm{mM} \mathrm{NaH}_{2} \mathrm{PO}_{4} \mathrm{pH}$ 8.0, $300 \mathrm{mM}$ $\mathrm{NaCl}$, and $500 \mathrm{mM}$ imidazole. Eluates from Ni-NTA purification were concentrated and further purified using a Superdex 200 10/30 GL column in a buffer comprising of $20 \mathrm{mM}$ HEPES pH 7.5 and $150 \mathrm{mM} \mathrm{NaCl}$.

For SPR, SARS-CoV-2 spike was chemically biotinylated at the $N$-terminus using EZ-link ${ }^{\mathrm{TM}}$ NHS-Biotin and performing the biotinylation reaction overnight at $\mathrm{pH} 6.5$ and $4{ }^{\circ} \mathrm{C}$. SARS-CoV-2 RBD was enzymatically biotinylated at the $C$-terminal Avitag ${ }^{\text {TM }}$ by co-transfecting RBD with a BirA expression construct and supplementing the culture media with $100 \mu \mathrm{M}$ biotin during expression. 


\subsection{SDS-PAGE}

Protein concentration was measured by Bradford Protein Assay Kit (Pierce, Waltham, MA, USA). Standards used Bovine Serum Albumin (BSA). Absorbance was read at $595 \mathrm{~nm}$. Protein samples were diluted in NuPAGE Sample Reducing Agent (10X) and NuPAGE LDS Sample Buffer $(4 \times)$ and boiled for 5 min before loading on 4-12\% Bis-Tris NuPAGE gradient gel (Thermo Scientific, Waltham, MA, USA). Proteins were stained with Sypro ruby or Colloidal blue (Thermo Scientific) for visualisation. Molecular masses were estimated by comparison with a Page Ruler Prestained Protein Ladder (Thermo Scientific).

\subsection{Enzyme Assays}

Enzyme activity was measured as previously described [56] and detailed in Supplementary Material A. Hydrolysis of the DPP4 substrate H-Gly-Pro-pNA was measured by absorbance at $405 \mathrm{~nm}$, with $570 \mathrm{~nm}$ for background subtraction, each $30 \mathrm{~s}$ for $10 \mathrm{~min}$ at $37^{\circ} \mathrm{C}$. A unit (U) of activity is defined as an enzyme activity that hydrolyses $1.0 \mu \mathrm{mol}$ of substrate per minute at $37^{\circ} \mathrm{C}$.

\subsection{Surface Plasmon Resonance Assay}

SPR was performed using a BIAcore T200 instrument (Cytiva) and conditions similar to methods described for investigating DPP4 and ACE2 binding with the spike and RBD of MERS [26,27]. Biotinylated SARS-CoV-2 spike and SARS-CoV-2 RBD were immobilised onto either a CM5 chip (Cytiva) via amine coupling or a biotin CAPture chip (Cytiva). Both spike and RBD proteins of SARS-CoV-2 were immobilised on the CM5 chip at about 500 response units. SARS-CoV-2 spike was immobilised on the biotin CAPture chip at $~ 500$ response units, and SARS-CoV-2 RBD was immobilised on the biotin CAPture chip at $\sim 50$ response units. Single-cycle kinetic experiments for the binding of ACE2 $(0.50 \mathrm{nM}, 2.5 \mathrm{nM}, 12 \mathrm{nM}, 62 \mathrm{nM}$ and $310 \mathrm{nM})$ and human soluble DPP4 $(0,1.6 \mathrm{nM}, 8.0 \mathrm{nM}, 40 \mathrm{nM}$, $200 \mathrm{nM}$ and $1000 \mathrm{nM}$ ) were performed at $25^{\circ} \mathrm{C}$ using an HBS-EP buffer consisting of $10 \mathrm{mM}$ HEPES, $\mathrm{pH} 7.5,150 \mathrm{mM} \mathrm{NaCl}, 3 \mathrm{mM}$ EDTA and $0.01 \%(v / v)$ Tween-20 as the running buffer. The sensor surface was regenerated using an injection of $5 \mathrm{mM} \mathrm{NaOH}$ between each cycle when required. Binding kinetics were analysed with the software BIAevaluation Version 3.1 using the 1:1 Langmuir binding model.

\subsection{ELISA}

Binding of recombinant DPP4 to MERS-CoV spike clamp protein was determined via ELISA. Recombinant DPP4 was diluted to $2 \mu \mathrm{g} / \mathrm{mL}$ in PBS, and $50 \mu \mathrm{L}$ was coated on a Nunc MaxiSorp ${ }^{\text {TM }}$ high protein-binding capacity 96 well ELISA plate overnight at $4{ }^{\circ} \mathrm{C}$. Plates were blocked with $150 \mu \mathrm{L} /$ well of 5\% KPL Milk Dilutent/Blocking solution concentrate (SeraCare, Milford, MA, USA) in PBS with $0.05 \%$ Tween-20 for $30 \mathrm{~min}$ at room temperature. Next, serial dilutions of MERS-CoV or SARS-CoV-2 spike protein, or a control protein, were added and incubated for $1 \mathrm{~h}$ at $37^{\circ} \mathrm{C}$. Plates were then washed three times with PBS with $0.05 \%$ Tween-20 before incubation with $2 \mu \mathrm{g} / \mathrm{mL}$ of an antibody towards the clamp domain, HIV1281 [57]. Plates were washed as before and incubated with a goat anti-human HRP secondary antibody (1:2000 dilution, Sigma Aldrich) for $1 \mathrm{~h}$ at $37^{\circ} \mathrm{C}$. Plates were washed a final time before the binding was revealed by the addition of tetramethylbenzidine (TMB) solution (Life Technologies) for $5 \mathrm{~min}$. Reactions were stopped by the addition of $1 \mathrm{M}$ sulfuric, acid and absorbance read at $450 \mathrm{~nm}$. Absorbance was plotted using Graphpad Prism software version 8 using a one-site specific binding model.

\subsection{MERS-CoV Pseudovirus Assay}

MERS-CoV pseudovirus was made as previously described [58]. Briefly, HEK293T cells were seeded in DMEM 10\% FCS (D10) media (Invitrogen) at a density of $2 \times 10^{6}$ cells in a $10 \mathrm{~cm}^{2}$ dish and incubated at $37{ }^{\circ} \mathrm{C} 5 \% \mathrm{CO}_{2}$. The following day, cells were transfected with $1 \mu \mathrm{g}$ of MERS-CoV full-length spike (residues 1-1353, GenBank: AHX00711.1), constructed using a gBlock (Integrated DNA Technologies, Coralville, IO, USA), the CMV promoter and infusion cloning (TakaraBio, Mountain 
View, CA, USA) in pNBF, along with $1 \mu \mathrm{g}$ p8.91 (encoding HIV-1 gag-pol) and $1.5 \mu \mathrm{g}$ pCSFLW [58] (encoding firefly luciferase reporter lentivirus backbone) with $14 \mu \mathrm{L}$ Lipofectamine LTX and $3.5 \mu \mathrm{L}$ PLUS reagent (Invitrogen) and incubated at $37^{\circ} \mathrm{C} 5 \% \mathrm{CO}_{2}$. The next day, the transfection mix was removed and replaced with $7 \mathrm{~mL}$ D10 media and incubated for a further $24 \mathrm{hrs}$. The virus was then harvested, and media was replaced for additional harvests 12 and 24 hrs later. Pooled harvests were centrifuged at $4{ }^{\circ} \mathrm{C}$ for $10 \mathrm{~min}$ at $1300 \times g$ to remove cellular debris. To measure MERS-CoV pseudovirus titer, target Huh-7 cells (Japanese Collection of Research Bioresources) were plated at a density of $2 \times 10^{4}$ cells/well of a white Nunc MicroWell ${ }^{\mathrm{TM}}$ 96-well plate in D10 media and incubated at $37^{\circ} \mathrm{C}$ $5 \% \mathrm{CO}_{2}$. The next day, MERS-CoV pseudovirus was titrated on target cells 5-fold in D10 media and incubated at $37^{\circ} \mathrm{C} 5 \% \mathrm{CO}_{2}$. After $72 \mathrm{hrs}$, firefly luciferase reporter activity was measured by discarding supernatant and adding $50 \mu \mathrm{L} /$ well of a 1:1 mix of Bio-Glo Luciferase Assay System (Promega) and serum-free DMEM. The plate was incubated for $10 \mathrm{~min}$ at room temperature before reading on a Varioskan LUX (ThermoFisher).

To measure virus inhibition, target Huh-7 cells were plated at a density of $2 \times 10^{4}$ cells per well of white Nunc MicroWell ${ }^{\mathrm{TM}}$ 96-well plate in D10 media and incubated at $37{ }^{\circ} \mathrm{C} 5 \% \mathrm{CO}_{2}$. The next day, inhibitors DPP4, ACE2 and Mab m336 [59], and non-specific mAb control C05 [57], were each diluted to an appropriate concentration in D10 media and incubated with MERS-CoV pseudovirus, at a dilution that would yield $\sim 2 \times 10^{6} \mathrm{RLU}$, for $1 \mathrm{hr}$ at $37^{\circ} \mathrm{C} 5 \% \mathrm{CO}_{2}$. Inhibitor/virus mixture was then added on to Huh-7 cells and incubated for a further $72 \mathrm{hrs}$ at $37^{\circ} \mathrm{C} 5 \% \mathrm{CO}_{2}$. Firefly luciferase reporter activity was quantified for virus titration.

\subsection{Protein Structure Depictions}

Structures of SARS-CoV-2 spike RBD [48], and human DPP4 complexed with MERS-CoV spike receptor-binding domain [45] and with human ADA [46] are available in the PDB, with access codes 6M0J, 4L72 and 1W1I, respectively. Protein structures were visualised and images generated using PyMOL software (Schrodinger LLC.; version 2.4.1; New York, NY, USA).

Supplementary Materials: The following are available online. Figure S1: Precipitation of soluble DPP4 from culture supernatant at various saturations levels of ammonium sulphate; Figure S2: Purified DPP4 on SDS-page; Figure S3: Surface plasmon resonance assay characterising binding between DPP4 and SARS-CoV-2 RBD and spike with a biotin CAPture chip; Supplementary Material A: Methods of assay and storage for purified recombinant soluble human DPP4 protein.

Author Contributions: Conceptualisation and supervision, M.D.G.; G.W.M.; W.B.C.; J.P.M.; Methodology, M.D.G.; H.E.Z.; N.A.N.; C.D.; J.K.K.L.; Y.C.; A.J.V.d.R.; B.O.; W.B.C.; J.P.M.; C.L.D.M.; A.I.; formal analysis, C.R.X.; A.D.F.; M.D.G., N.A.N.; C.M.; A.I.; investigation, A.D.F.; N.A.N.; C.R.X.; X.T.W.; K.P.; M.S.W.X.; writing-original draft preparation, C.R.X.; K.P.; writing-review and editing, M.D.G.; N.A.N.; A.D.F., J.K.K.L., W.B.C.; J.P.M.; C.L.M.; A.I.; visualisation, C.R.X.; K.P.; A.D.F.; funding acquisition, M.D.G.; G.W.M. All authors have read and agreed to the published version of the manuscript.

Funding: This research was funded by project grant 1105238 to M.D.G. and G.W.M. and Program Grant 571408 to G.W.M. from the Australian National Health and Medical Research Council and grants to M.D.G. and W.B.C. from the Rebecca L. Cooper Medical Research Foundation.

Acknowledgments: The authors thank Florian Krammer of the Icahn School of Medicine, Mt Sinai, for the SARS-CoV-2 spike plasmid, and Keith Chappell of The University of Queensland for advice.

Conflicts of Interest: The authors declare no conflict of interest. DPP4 enzyme produced as described here is sold by Sigma-Aldrich, with catalogue number D4943, with a financial benefit to the research led by M.D.G.

\footnotetext{
Abbreviations

Adenosine deaminase binding protein (ADAbp), diethylaminoethyl (DEAE), dipeptidyl peptidase 4 (DPP4), type 2 diabetes mellitus (T2DM), glucagon-like peptide-1 (GLP-1), gastric inhibitory polypeptide (GIP), angiotensin-converting enzyme 2 (ACE2), receptor-binding domain (RBD), severe acute respiratory syndrome (SARS), middle east respiratory syndrome (MERS), surface plasmon resonance (SPR), ammonium sulphate (AS), hydrophobic interaction chromatography (HIC), immobilised metal affinity chromatography (IMAC), ion-exchange chromatography (IEX), Spodoptera frugiperda 9 (Sf9), multiplicity of infection (MOI), polyethyleneimine (PEI).
} 


\section{References}

1. Dunaevsky, Y.E.; Tereshchenkova, V.F.; Oppert, B.; Belozersky, M.A.; Filippova, I.Y.; Elpidina, E.N. Human proline specific peptidases: A comprehensive analysis. Biochim. Biophys. Acta 2020, 1864, 129636. [CrossRef] [PubMed]

2. Enz, N.; Vliegen, G.; De Meester, I.; Jungraithmayr, W. CD26/DPP4-a potential biomarker and target for cancer therapy. Pharmacol. Ther. 2019, in press. [CrossRef] [PubMed]

3. Gorrell, M.D. Dipeptidyl peptidase IV and related enzymes in cell biology and liver disorders. Clin. Sci. 2005, 108, 277-292. [CrossRef] [PubMed]

4. Rosenstock, J.; Perkovic, V.; Johansen, O.E.; Cooper, M.E.; Kahn, S.E.; Marx, N.; McGuire, D.K. Effect of Linagliptin vs. Placebo on Major Cardiovascular Events in Adults with Type 2 Diabetes and High Cardiovascular and Renal Risk: The CARMELINA Randomized Clinical Trial. JAMA 2019, 321, 69-79. [CrossRef]

5. Tanaka, T.; Duke-Cohan, J.S.; Kameoka, J.; Yaron, A.; Lee, I.; Schlossman, S.F.; Morimoto, C. Enhancement of antigen-induced T-cell proliferation by soluble CD26/dipeptidyl peptidase IV. Proc. Natl Acad. Sci. USA 1994, 91, 3082-3086. [CrossRef]

6. Wang, X.M.; Holz, L.E.; Chowdhury, S.; Cordoba, S.P.; Evans, K.A.; Gall, M.G.; Gorrell, M.D. Profibrotic role of dipeptidyl peptidase 4 in a carbon tetrachloride induced experimental liver injury. Immunol. Cell Biol. 2017, 95, 443-453. [CrossRef]

7. De Meester, I.; Vanham, G.; Kestens, L.; Vanhoof, G.; Bosmans, E.; Gigase, P.; Scharpé, S. Binding of adenosine deaminase to the lymphocyte surface via CD26. Eur. J. Immunol. 1994, 24, 566-570. [CrossRef]

8. De Meester, I.; Vanhoof, G.; Lambeir, A.M.; Scharpé, S. Use of immobilised adenosine deaminase (EC 3.5.4.4) for the rapid purification of native human CD26 dipeptidyl peptidase IV (EC 3.4.14.5). J. Immunol. Methods 1996, 189, 99-105. [CrossRef]

9. Weihofen, W.A.; Liu, J.; Reutter, W.; Saenger, W.; Fan, H. Crystal structure of CD26/Dipeptidyl-peptidase IV in complex with adenosine deaminase reveals a highly amphiphilic interface. J. Biol. Chem. 2004, 41, 43330-43335. [CrossRef]

10. Yu, D.M.T.; Slaitini, L.; Gysbers, V.; Riekhoff, A.G.M.; Kähne, T.; Knott, H.M.; Gorrell, M.D. Soluble CD26/dipeptidyl peptidase IV enhances human lymphocyte proliferation in vitro independent of dipeptidyl peptidase enzyme activity and adenosine deaminase binding. Scand. J. Immunol. 2011, 73, 102-111. [CrossRef]

11. Ghorpade, D.S.; Ozcan, L.; Zheng, Z.; Nicoloro, S.M.; Shen, Y.; Chen, E.; Tabas, I. Hepatocyte-secreted DPP4 in obesity promotes adipose inflammation and insulin resistance. Nature 2018, 555, 673. [CrossRef] [PubMed]

12. Moffitt, L.R.; Bilandzic, M.; Wilson, A.L.; Chen, Y.; Gorrell, M.D.; Oehler, M.K.; Stephens, A.N. Hypoxia regulates DPP4 expression, proteolytic inactivation and shedding from ovarian cancer cells. Int. J. Mol. Sci. 2020, 21, 8110. [CrossRef] [PubMed]

13. Aertgeerts, K.; Ye, S.; Tennant, M.G.; Collins, B.; Rogers, J.; Sang, B.; Prasad, G.S. Crystal structure of human Dipeptidyl Peptidase IV in complex with a decapeptide reveals details on substrate specificity and tetrahedral intermediate formation. Protein Sci. 2004, 13, 412-421. [CrossRef] [PubMed]

14. Rasmussen, H.B.; Branner, S.; Wiberg, F.C.; Wagtmann, N. Crystal structure of human DPP-IV/CD26 in complex with a substrate analogue. Nat. Struct. Mol. Biol. 2003, 10, 19-25. [CrossRef]

15. Bishnoi, R.; Hong, Y.R.; Shah, C.; Ali, A.; Skelton, W.P.T.; Huo, J.; Dang, L.H. Dipeptidyl peptidase 4 inhibitors as novel agents in improving survival in diabetic patients with colorectal cancer and lung cancer: A Surveillance Epidemiology and Endpoint Research Medicare study. Cancer Med. 2019, 8, 3918-3927. [CrossRef]

16. Deacon, C.F. Physiology and Pharmacology of DPP-4 in Glucose Homeostasis and the Treatment of Type 2 Diabetes. Front. Endocrinol. 2019, 10, 80. [CrossRef]

17. Kirby, M.S.; Yu, D.M.T.; O'Connor, S.P.; Gorrell, M.D. Inhibitor selectivity in the clinical application of dipeptidyl peptidase-4 inhibition. Clin. Sci. 2010, 118, 31-41. [CrossRef]

18. Mentlein, R.; Dahms, P.; Grandt, D.; Kruger, R. Proteolytic processing of neuropeptide Y and peptide YY by dipeptidyl peptidase IV. Regul. Pept. 1993, 49, 133-144. [CrossRef] 
19. Abbott, C.A.; McCaughan, G.W.; Levy, M.T.; Church, W.B.; Gorrell, M.D. Binding to human dipeptidyl peptidase IV by adenosine deaminase and antibodies that inhibit ligand binding involves overlapping, discontinuous sites on a predicted $\beta$ propeller domain. Chem. Eur. J. 1999, 266, 798-810. [CrossRef]

20. Aertgeerts, K.; Ye, S.; Shi, L.; Prasad, S.G.; Witmer, D.; Chi, E.; Swanson, R.V. N-linked glycosylation of dipeptidyl peptidase IV (CD26): Effects on enzyme activity, homodimer formation, and adenosine deaminase binding. Protein Sci. 2004, 13, 145-154. [CrossRef]

21. Bassendine, M.F.; Bridge, S.H.; McCaughan, G.W.; Gorrell, M.D. COVID-19 and comorbidities: A role for dipeptidyl peptidase 4 (DPP4) in disease severity? J. Diabetes Res. 2020, 12, 649-658. [CrossRef]

22. Du, H.; Wang, D.W.; Chen, C. The potential effects of DPP-4 inhibitors on cardiovascular system in COVID-19 patients. J. Cell. Mol. Med. 2020, 24, 10274-10278. [CrossRef] [PubMed]

23. Varin, E.M.; Mulvihill, E.E.; Beaudry, J.L.; Pujadas, G.; Fuchs, S.; Tanti, J.F.; Drucker, D.J. Circulating Levels of Soluble Dipeptidyl Peptidase-4 Are Dissociated from Inflammation and Induced by Enzymatic DPP4 Inhibition. Cell Metab. 2018, 29, 320-334.e5. [CrossRef] [PubMed]

24. Lu, R.; Zhao, X.; Li, J.; Niu, P.; Yang, B.; Wu, H.; Tan, W. Genomic characterisation and epidemiology of 2019 novel coronavirus: Implications for virus origins and receptor binding. Lancet 2020, 395, 565-574. [CrossRef]

25. Verity, R.; Okell, L.C.; Dorigatti, I.; Winskill, P.; Whittaker, C.; Imai, N.; Ferguson, N.M. Estimates of the severity of coronavirus disease 2019: A model-based analysis. Lancet Infect. Dis. 2020, 20, 669-677. [CrossRef]

26. Lu, G.; Hu, Y.; Wang, Q.; Qi, J.; Gao, F.; Li, Y.; Gao, G.F. Molecular basis of binding between novel human coronavirus MERS-CoV and its receptor CD26. Nature 2013, 500, 227-231. [CrossRef] [PubMed]

27. Song, W.; Wang, Y.; Wang, N.; Wang, D.; Guo, J.; Fu, L.; Shi, X. Identification of residues on human receptor DPP4 critical for MERS-CoV binding and entry. Virology 2014, 471-473, 49-53. [CrossRef]

28. Vankadari, N.; Wilce, J.A. Emerging WuHan (COVID-19) coronavirus: Glycan shield and structure prediction of spike glycoprotein and its interaction with human CD26. Emerg. Microbes Infect. 2020, 9, 601-604. [CrossRef]

29. Hoffmann, M.; Kleine-Weber, H.; Schroeder, S.; Kruger, N.; Herrler, T.; Erichsen, S.; Pohlmann, S. SARS-CoV-2 Cell Entry Depends on ACE2 and TMPRSS2 and Is Blocked by a Clinically Proven Protease Inhibitor. Cell 2020, 181, 271-280 e8. [CrossRef]

30. Shang, J.; Ye, G.; Shi, K.; Wan, Y.; Luo, C.; Aihara, H.; Li, F. Structural basis of receptor recognition by SARS-CoV-2. Nature 2020, 581, 221-224. [CrossRef]

31. Shang, J.; Wan, Y.; Luo, C.; Ye, G.; Geng, Q.; Auerbach, A.; Li, F. Cell entry mechanisms of SARS-CoV-2. Proc. Natl. Acad. Sci. USA 2020, 117, 11727-11734. [CrossRef] [PubMed]

32. Zhou, P.; Yang, X.L.; Wang, X.G.; Hu, B.; Zhang, L.; Zhang, W.; Shi, Z.L. A pneumonia outbreak associated with a new coronavirus of probable bat origin. Nature 2020, 579, 270-273. [CrossRef] [PubMed]

33. Letko, M.; Marzi, A.; Munster, V. Functional assessment of cell entry and receptor usage for SARS-CoV-2 and other lineage B betacoronaviruses. Nat. Rev. Microbiol. 2020, 5, 562-569. [CrossRef] [PubMed]

34. Dobers, J.; Zimmermann-Kordmann, M.; Leddermann, M.; Schewe, T.; Reutter, W.; Fan, H. Expression, purification, and characterization of human dipeptidyl peptidase IV/CD26 in Sf9 insect cells. Protein Expr. Purif. 2020, 25, 527-532. [CrossRef]

35. Park, J.; Knott, H.M.; Nadvi, N.A.; Collyer, C.A.; Wang, X.M.; Church, W.B.; Gorrell, M.D. Reversible inactivation of human dipeptidyl peptidases 8 and 9 by oxidation. Open Enzym. Inhib. J. 2008, 1, 52-61. [CrossRef]

36. Thoma, R.; Loffler, B.; Stihle, M.; Huber, W.; Ruf, A.; Hennig, M. Structural basis of proline-specific exopeptidase activity as observed in human dipeptidyl peptidase-IV. Structure 2003, 11, 947-959. [CrossRef]

37. Jarvis, D.L. Baculovirus-insect cell expression systems. Meth. Enzymol. 2009, 463, 191-222. [CrossRef]

38. Mannix, C.; Jarman, R.F. A Guide to Successful Scale-up of the Baculovirus Expression System. In Cell Engineering; Al-Rubeai, M., Ed.; Springer: Dordrecht, The Netherlands, 2020. [CrossRef]

39. Ajami, K.; Pitman, M.R.; Wilson, C.H.; Park, J.; Menz, R.I.; Starr, A.E.; Cox, J.H.; Abbott, C.A.; Overall, C.M.; Gorrell, M.D. Stromal cell-derived factors 1 alpha and 1 beta, inflammatory protein-10 and interferon-inducible T cell chemo-attractant are novel substrates of dipeptidyl peptidase 8. FEBS Lett. 2008, 582, 819-825. [CrossRef] 
40. Ajami, K.; Abbott, C.A.; Obradovic, M.; Gysbers, V.; Kähne, T.; McCaughan, G.W.; Gorrell, M.D. Structural requirements for catalysis, expression and dimerisation in the CD26/DPIV gene family. Biochemistry 2003, 42, 694-701. [CrossRef]

41. Oravecz, T.; Pall, M.; Roderiquez, G.; Gorrell, M.D.; Ditto, M.; Nguyen, N.Y.; Norcross, M.A. Regulation of the receptor specificity and function of the chemokine RANTES (regulated on activation normal T cell expressed and activated) by dipeptidyl peptidase IV (CD26)-mediated cleavage. J. Exp. Med. 1997, 186, 1865-1872. [CrossRef]

42. Osborne, B.; Yao, T.-W.; Wang, X.M.; Chen, Y.; Kotan, L.D.; Nadvi, N.A.; Gorrell, M.D. A rare variant in human fibroblast activation protein associated with ER stress, loss of function and loss of cell surface localisation. Biochim. Biophys. Acta 2014, 1844, 1248-1259. [CrossRef] [PubMed]

43. Buckley, S.J.; Collins, P.J.; O'Connor, B.F. The purification and characterisation of novel dipeptidyl peptidase IV-like activity from bovine serum. Int. J. Biochem. Cell Biol. 2014, 36, 1281-1296. [CrossRef] [PubMed]

44. Leatherbarrow, R.J.; Dean, P.D. Studies on the mechanism of binding of serum albumins to immobilised cibacron blue F3G A. Biochem. J. 1980, 189, 27-34. [CrossRef] [PubMed]

45. Wang, N.; Shi, X.; Jiang, L.; Zhang, S.; Wang, D.; Tong, P.; Wang, X. Structure of MERS-CoV spike receptor-binding domain complexed with human receptor DPP4. Cell Res. 2013, 23, 986-993. [CrossRef]

46. Weihofen, W.A.; Liu, J.; Reutter, W.; Saenger, W.; Fan, H. Crystal structures of HIV-1 Tat-derived nonapeptides Tat-(1-9) and Trp2-Tat-(1-9) bound to the active site of dipeptidyl-peptidase IV (CD26). J. Biol. Chem. 2015, 280, 14911-14917. [CrossRef]

47. Watanabe, Y.; Allen, J.D.; Wrapp, D.; McLellan, J.S.; Crispin, M. Site-specific analysis of the SARS-CoV-2 glycan shield. Science 2020, 369, 330-333. [CrossRef]

48. Lan, J.; Ge, J.; Yu, J.; Shan, S.; Zhou, H.; Fan, S.; Wang, X. Structure of the SARS-CoV-2 spike receptor-binding domain bound to the ACE2 receptor. Nature 2020, 581, 215-220. [CrossRef]

49. Daddona, P.E.; Kelley, W.N. Human adenosine deaminase binding protein. Assay, purification, and properties. J. Biol. Chem. 1978, 253, 4617-4623.

50. Sinnathurai, P.; Lau, W.; Vieira de Ribeiro, A.J.; Bachovchin, W.W.; Englert, H.; Howe, G.; Gorrell, M.D. Circulating fibroblast activation protein and dipeptidyl peptidase 4 in rheumatoid arthritis and systemic sclerosis. Int. J. Rheum. Dis. 2018, 21, 1915-1923. [CrossRef]

51. Teo, A.S.; Ramos, J.D.; Lee, B.W.; Cheong, N.; Chua, K.Y. Expression of the Blomia tropicalis paramyosin Blo t 11 and its immunodominant peptide in insect cells. Appl. Biochem. Biotechnol. 2006, 45, 13-21. [CrossRef]

52. Summers, M.D.; Smith, G.D. A manual of Methods for Baculovirus Vectors and Insect Cell Culture Procedures; Texas Agriculture Experiment Station Bulletin: College Station, TX, USA, 1978.

53. Abbott, C.A.; Yu, D.M.T.; Woollatt, E.; Sutherland, G.R.; McCaughan, G.W.; Gorrell, M.D. Cloning, expression and chromosomal localization of a novel human dipeptidyl peptidase (DPP) IV homolog, DPP8. Chem. Eur. J. 2020, 267, 6140-6150. [CrossRef]

54. Amanat, F.; Stadlbauer, D.; Strohmeier, S.; Nguyen, T.H.O.; Chromikova, V.; McMahon, M.; Krammer, F. A serological assay to detect SARS-CoV-2 seroconversion in humans. Nat. Med. 2020, 26, 1033-1036. [CrossRef] [PubMed]

55. Stadlbauer, D.; Amanat, F.; Chromikova, V.; Jiang, K.; Strohmeier, S.; Arunkumar, G.A.; Krammer, F. SARS-CoV-2 Seroconversion in Humans: A Detailed Protocol for a Serological Assay, Antigen Production, and Test Setup. Curr. Protoc. Microbiol. 2020, 57, e100. [CrossRef] [PubMed]

56. Keane, F.M.; Yao, T.-W.; Seelk, S.; Gall, M.G.; Chowdhury, S.; Poplawski, S.E.; Gorrell, M.D. Quantitation of fibroblast activation protein (FAP)-specific protease activity in mouse, baboon and human fluids and organs. FEBS Open Bio 2014, 4, 43-54. [CrossRef] [PubMed]

57. Frey, G.; Chen, J.; Rits-Volloch, S.; Freeman, M.M.; Zolla-Pazner, S.; Chen, B. Distinct conformational states of HIV-1 gp41 are recognized by neutralizing and non-neutralizing antibodies. Nat. Struct. Mol. Biol. 2010, 17, 1486-1491. [CrossRef] [PubMed] 
58. Grehan, K.; Ferrara, F.; Temperton, N. An optimised method for the production of MERS-CoV spike expressing viral pseudotypes. MethodsX 2015, 2, 379-384. [CrossRef]

59. Ying, T.; Du, L.; Ju, T.W.; Prabakaran, P.; Lau, C.C.; Lu, L.; Dimitrov, D.S. Exceptionally potent neutralization of Middle East respiratory syndrome coronavirus by human monoclonal antibodies. J. Virol. 2014, 88, 7796-7805. [CrossRef]

Sample Availability: Samples of novel materials are available from the authors.

Publisher's Note: MDPI stays neutral with regard to jurisdictional claims in published maps and institutional affiliations.

(C) 2020 by the authors. Licensee MDPI, Basel, Switzerland. This article is an open access article distributed under the terms and conditions of the Creative Commons Attribution (CC BY) license (http://creativecommons.org/licenses/by/4.0/). 